\title{
In-vitro Evaluation of Antifungal Activity of Ganoderma lucidum Against the Biofilm Producing Candida species
}

\author{
Naveen kumar $\mathbf{C}^{1 *}$, Jayalakshmi $\mathbf{G}^{2}$, Chidambaram $\mathbf{R}^{3}$, Srikumar $\mathbf{R}^{4}$ \\ ${ }^{1}$ Ph.D Research Scholar, Sri Lakshmi Narayana Institute of Medical Sciences, Osudu Lake, Koodapakkam, Pondicherry, INDIA \\ ${ }^{2}$ DEAN, Sri Lakshmi Narayana Institute of Medical Sciences, Osudu Lake, Koodapakkam, Pondicherry, INDIA. \\ ${ }^{3}$ Director of Research, Sri Lakshmi Narayana Institute of Medical Sciences, Osudu Lake, Koodapakkam, Pondicherry, INDIA. \\ ${ }^{4}$ Research Associate, Sri Lakshmi Narayana Institute of Medical Sciences, Osudu Lake, Koodapakkam, Pondicherry, INDIA.
}

\begin{abstract}
Background: Bioproducts of mushrooms Ganoderma lucidum have multi beneficial effects for human welfare. Objectives: The aim of the present study was to evaluate antifungal activity of Ganoderma lucidum against the biofilm producing fungi. In this current study it carries 100 Candida species which forms biofilms were collected from the Immunocompromised and Immuno Suppressive patients. Methods: The fruit bodies of Ganoderma lucidum were collected and done the extraction at various concentrations with the help of Dimethyl sulfoxide (DMSO) and Methanol. The various concentrations of the extracts were applied by Proteinase and phospholipase enzyme secretion assay, Minimum Inhibitory Concentration (MIC) - XTT Assay and Minimal Fungicidal Concentration (MFC). Results: Our results showed the MIC and MFC of DMSO extract were shows highest significant value $(P<0.05)$ against the antifungal activity than the methanolic extract of the Ganoderma lucidum among the various biofilm producing candida species. Conclusion: So we can be conclude that DMSO extract of the Ganoderma lucidum shows high significant factor against the various disease causing Candida species and its biofilm.
\end{abstract}

Key words: Ganoderma lucidum, Biofilms, Candida species, Proteinase, Phospholipase, DMSO and Methanol extracts.

\section{INTRODUCTION}

Edible Medicinal mushrooms have an established history of use in traditional oriental therapies and new antimicrobial drugs. ${ }^{1,2,3}$ Modern clinical practice in Japan, China, Korea, and other Asian countries continues to relay on medicinal mushroom Ganoderma lucidum derived preparations. ${ }^{4,5}$ One interesting aspect of its performance is antimicrobial effect due to the extracts derived from this mushroom which contain bacteriolytic enzyme, lysozyme and acid protease. ${ }^{6}$ There are available in literature some studies reporting antimicrobial activity of different extracts of Ganoderma lucidum. ${ }^{7,89}$ Immunocompromised and Immunosuppressive patients are prone to get secondary infec- tions in that the main part belongs to the fungal infections. Fungi most commonly associated with such disease episodes are in the genus Candida, most notably Candida albicans, which causes both superficial and systemic disease. Non albican candida (NAC) like Candida glabrata, Candida parapsilosis, Candida tropicalis, Candida krusei, Candida kefyr, etc are also causes various infections like Urinary tract infections, Vaginitis, Oropharyngeal infections, Onychomycosis, Candidemia, and other device related infections. ${ }^{10,11,12}$ Even with current antifungal therapy, mortality of patients with invasive candidiasis can be as high as $40 \% .^{13}$ Nutrients, quorum-sens-
Submission Date: 13-04-2017; Revision Date: 01-06-2017; Accepted Date: 22-07-2017

DOI: 10.5530/ijper.51.4s.91 Correspondence: Dr. C. Naveen kumar,

Ph.D. Research Scholar, Sri Lakshmi Narayana Institute of Medical Sciences, Osudu Lake, Koodapakkam PO, Pondicherry - 605502, INDIA.

Phone no. +919047765601 E-mail: navin.mmb@gmail. com

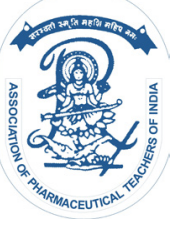

www.ijper.org 
ing molecules and surface contact are contributory factors of C. albicans (SC5314) are comprised primarily of yeast-form and hyphal cells, both of which are required for biofilm formation. ${ }^{14}$ Biofilms are studied in a wide range of scientific disciplines including biomedicine. ${ }^{15,16}$ Biofilm formation is also critical in the development of denture stomatitis, a superficial form of candidiasis that affects $65 \%$ of edentulous individuals. ${ }^{17,18}$ These clinical observations emphasize the importance of biofilm formation to both superficial and systemic candidiasis and the inability of current antifungal therapy to cure such diseases. Estimates suggest that up to $80 \%$ of all microorganisms in the environment exist in biofilm communities. ${ }^{19}$ Current treatments for Candida species infection consist of topical and systemic pharmaceutical antifungal agents, with triazoles being the first line of defense are effective. ${ }^{20}$ The Proteinase and phospholipase enzyme are the virulence factors causes the cell damage of the host. ${ }^{21}$ The present in vitro study screens that the modifications among those enzymes which causes by the antifungal activity of the Ganoderma extracts. Furthermore the MIC and MFC has been performed to screen the level of the growth inhibition of biofilm candida species. Therefore, this study aims to primarily evaluate the in vitro action of the antifungal activity of DMSO and Methanol extracts of the Ganoderma lucidum against Candida species which can produce the biofilms. ${ }^{22}$

\section{MATERIALS AND METHODS Sample Collection}

About 162 samples were collected and screened for the candida infections have been illustrated in Table 1 . Among 162 samples 100 isolates were screened and identified various Candida species in this present study. All the samples were collected from the both the immunocompromised and immunosuppressed patients who were admitted in the Sri Lakshmi Narayana Institute of Medical Science, Pondicherry. The isolates sample distributions were explained in the Table 2. All the isolates were grown in various media like Sabouraud dextrose agar, Chrom agar, Potato dextrose agar to get pure culture of the various candida species. All the isolates were speciated by screening of various tests like germ tube, carbohydrate assimilation test, Chlamydospore formation, Sugar fermentation, etc. About 09 candida species (Candida albicans, Candida glabrata, Candida parapsilosis, Candida tropicalis, Candida krusei, Candida kefyr, Candida guilliermondi, Candida lusitaniae and Candida dubliniensis) were isolated, speciated and treated against the crude extract of Ganoderma lucidum to screen antifungal activity.

\section{Collection of Ganoderma lucidum}

Ganoderma lucidum mushroom were collected from the field near Aurovile, MKV Organics, Puducherry. Taxonomy identification by their physical characteristics of the mushroom was done based on the Sporocarps and Basidiocarps. ${ }^{23,24,25}$ Specimens collected from above mentioned place were brought to laboratory and rinsed with distilled water. Furthermore, dried under heater fan at $40^{\circ} \mathrm{C}$ for 2 hours and then preserved in freezer at $-200^{\circ} \mathrm{C}$ to use for further processing. Ganoderma species was identified using keys provided. ${ }^{26}$

\section{Powderization}

The basidiocarps were cut in to small pieces, dried at $40^{\circ} \mathrm{C}$ for 48 hours and powdered. In each step, the fine product was dried to remove moisture and overcome the fungal contamination. The air-dried powder was stored in an air tight container for further use. ${ }^{27}$

\section{Extract Preparation}

The powder of dried Ganoderma lucidum was used for the preparation of mushroom extract. For the dimethyl sulfoxide (DMSO) extraction $50 \mathrm{~g}$ of mushroom powder were mixed with $100 \mathrm{ml}$ of DMSO and placed on a shaker for $24 \mathrm{~h}$ at room temperature. The solution was filtered with $3 \mathrm{M}^{\mathrm{TM}} 740$ Cartridge and then placed on the rotary evaporator vacuum, for $15 \mathrm{~min}$ at $37^{\circ} \mathrm{C}$. Then the residue was stored at $4^{\circ} \mathrm{C}$ for further analysis. The methanolic extract was performed through Soxhlet apparatus of the experimental samples were prepared by adding $50 \mathrm{~g}$ of mushroom powder was subjected for extraction using of $100 \mathrm{ml}$ of Methanol at room temperature for $24 \mathrm{hrs}$ and filtered through Whatman No. 4 filter paper. The extracts were recovered by filtration and kept at $40^{\circ} \mathrm{C}$ in a rotary vacuum evaporator. ${ }^{28}$ the residue was collected and store at $4^{\circ} \mathrm{C}$ for further use. The crude extracts were dissolved in both DMSO and Methanol to get various concentrations $(150 \mu \mathrm{g} / \mathrm{ml}, 200 \mu \mathrm{g} / \mathrm{ml}$, $250 \mu \mathrm{g} / \mathrm{ml}, 300 \mu \mathrm{g} / \mathrm{ml}$ and $350 \mu \mathrm{g} / \mathrm{ml})$.

\section{Screening of antifungal activity of mushroom extract}

The antimicrobial activities of the extracts were determined by the Kirby-Bauer broth dilution method according to NCCLS standards. ${ }^{29,30}$ The fungal cultures were incubated at room temperature for 48 hours in CHROM agar for the presumptive identification of several Candida species by using color reactions. For control Candida albicans ATCC SC5314 bioflim producer was used for antifungal activity. 
Screening Proteinase and phospholipase enzyme secretion assay

Biofilms of Candida species were grown for $24 \mathrm{hrs}$ in Yeast Nitrogen Base Medium (YNB) with $50 \mathrm{mM}$ of glucose at $37^{\circ} \mathrm{C}$ in $5 \% \mathrm{CO}_{2}$ and treated with Ganoderma crude extract concentrations of $150 \mu \mathrm{g} / \mathrm{ml}-350 \mu \mathrm{g} / \mathrm{ml}$. Trypsin (for proteinase assay) and Phospholipase A2 (for phospholipase assay) were used to perform the assay. The control used in this assay was $1 \%$ ethanol. After 72 hrs of biofilm maturation, the enzyme secretion assays were performed on biofilms suspended in Phosphate Buffer Saline (PBS). The proteinase enzyme activity was determined by mixing the supernatant of the biofilm solution with $1 \%$ azocasein at $1 \mathrm{~h}$ at $37^{\circ} \mathrm{C}$ in $5 \% \mathrm{CO}_{2}$. Then, $500 \mathrm{ml}$ of $10 \%$ trichloroacetic acid was added to stop the reaction. The solution was centrifuged for $5 \mathrm{~min}$ at $10,000 \mathrm{rpm}$ and $500 \mathrm{ml}$ of the supernatant was combined with $500 \mathrm{ml}$ of $\mathrm{NaOH}$, which was incubated for $15 \mathrm{~min}$ at $37^{\circ} \mathrm{C}$ in $5 \% \mathrm{CO}_{2}$. Absorbance was read in a spectrophotometer at $440 \mathrm{~nm} \cdot{ }^{31,32,33}$ The phospholipase enzyme activity was determined by mixing the supernatant of the biofilm solution with phosphatidylcholine substrate for $1 \mathrm{hr}$ at $37^{\circ} \mathrm{C}$ in $5 \%$ $\mathrm{CO}_{2}$ and reading the absorbance in a spectrophotometer at $630 \mathrm{~nm}^{34}$

\section{Screening of Minimum Inhibitory Concentration (MIC)}

The minimum inhibitory concentration (MIC) was performed in the XTT reduction assay. ${ }^{35,36}$ Biofilms were produced on commercially available presterilized, polystyrene, flat-bottom 96-well microtiter plates. $100 \mu \mathrm{L}$ of C. albicans and other species of candida cell suspension was transferred into each well of a microtiter plate which contains Roswell Park Memorial Institute (RPMI) 1640 media, and the plate was incubated for 2 hours at $37^{\circ} \mathrm{C}$ in a shaker at $75 \mathrm{rpm}$ to allow for adherence to the surface of the wells. Three wells of each microtiter plate were used as control in an identical fashion, except that no Candida suspensions were added. Following the adhesion phase, the cell suspensions were aspirated and each well was washed twice with $150 \mu \mathrm{L}$ of Phosphate Buffer Saline (PBS) to remove loosely adherent cells. A total of $100 \mu \mathrm{L}$ of RPMI 1640 was then transferred into each of the washed wells with a pipette, and the plates were incubated at $37^{\circ} \mathrm{C}$ in a shaker at $75 \mathrm{rpm}$. After the incubation media has been aspirated and both the extracts have been added separately of various concentrations $150 \mu \mathrm{g} / \mathrm{ml}-350 \mu \mathrm{g} / \mathrm{ml}$ has mentioned earlier. The plate was incubated for $24 \mathrm{~h}$ at $37^{\circ} \mathrm{C}$ in $5 \%$ $\mathrm{CO}_{2} \cdot{ }^{37}$ After the supernatant aspiration each well of $100 \mu \mathrm{l}$ of XTT (2,3-bis (2-methoxy-4-nitro-5-sulfophenyl)-
2H-tetrazolium-5-carboxanilide) added and incubate in the dark area $2-3 \mathrm{hrs}$ at $37^{\circ} \mathrm{C} .^{38,39}$ The visual inspection of the plates will typically demonstrate a gradient of orange color. Further read the plate in a microtiter plate reader at $490 \mathrm{~nm}$. From the resulting colorimetric readings the fungal isolates and it OD Value has been calculated.

\section{Minimal Fungicidal Concentration (MFC)}

Minimum fungicidal concentration (MFC) was done through micro dilution method. The content of each well containing various concentrations of extracts corresponding to read after $72 \mathrm{~h}^{40}$ By sub culturing $20 \mu \mathrm{l}$ of each well on Sabouraud Dextrose Agar and also in the Chrom agar after $24 \mathrm{~h}$ of incubation at $27^{\circ} \mathrm{C}$, MFC concentration was determined as the lowest concentration of Ganoderma Extracts, showing no visible $C$. albicans growth on the agar plates. ${ }^{41}$

\section{Data calculation}

Treated $(T)$ and control $(C)$ Petri dishes were measured diametrically in three different directions till the fungal growth in the control dishes was nearly far-reaching. The percentage of growth inhibition $(I)$ was calculated using the formula. ${ }^{42}$

$$
I(\%)=[(C-T) / C] \times 100
$$

\section{RESULT AND DISCUSSION}

The present study tested the antifungal activity of crude extracts and their respective dilutions from medicinal mushroom belonging to Ganoderma lucidum. The medicinal mushroom was chosen based on either traditional usage, suggestive of antifungal activity. The incidence of Candida albicans and other species isolated from the immune compromised and immune suppressed patients has been reported to be $23 \%$ of patients with undergoing chemotherapy, $35 \%$ in diabetic patients and $42 \%$ of patients with HIV. Candida species plays a most common cause of nosocomial bloodstream infections. Patients who are critically ill and in medical and surgical ICUs have been the prime targets for opportunistic nosocomial fungal infections, primarily due to Candida species.

Minimal inhibitory concentration (MIC) and minimum fungicidal concentration (MFC) were established for DMSO and Methanolic extracts from each of the 09 species. From the total extracts evaluated by the growth inhibition percentage formula, $82(82 \%)$ isolates were showed fungistatic activities and $78(78 \%)$ isolates were showed fungicidal activity. The MIC values ranged from 150 to $250 \mu \mathrm{g} / \mathrm{ml}$ and MFCs values ranged from 150 to $200 \mu \mathrm{g} / \mathrm{ml}$ of the both the extracts. DMSO extracts of 


\begin{tabular}{|c|c|c|c|c|}
\hline \multicolumn{7}{|c|}{ Table 1: Age and Sex Distribution of the Patients. } \\
\hline \multirow{2}{*}{ S. No } & Age Distribution of the Patients & Sex Distribution of the Patients & \multirow{2}{*}{ Total } \\
\cline { 2 - 4 } & & Male & Female & \multirow{2}{*}{31} \\
\hline 1 & $\leq 10$ & 17 & 14 & 13 \\
\hline 2 & $11-20$ & 8 & 5 & 21 \\
\hline 3 & $21-30$ & 9 & 12 & 23 \\
\hline 4 & $31-40$ & 8 & 15 & 17 \\
\hline 5 & $41-50$ & 10 & 7 & 17 \\
\hline 6 & $51-60$ & 9 & 8 & 40 \\
\hline 7 & $\geq 60$ & 22 & 18 & 162 \\
\hline
\end{tabular}

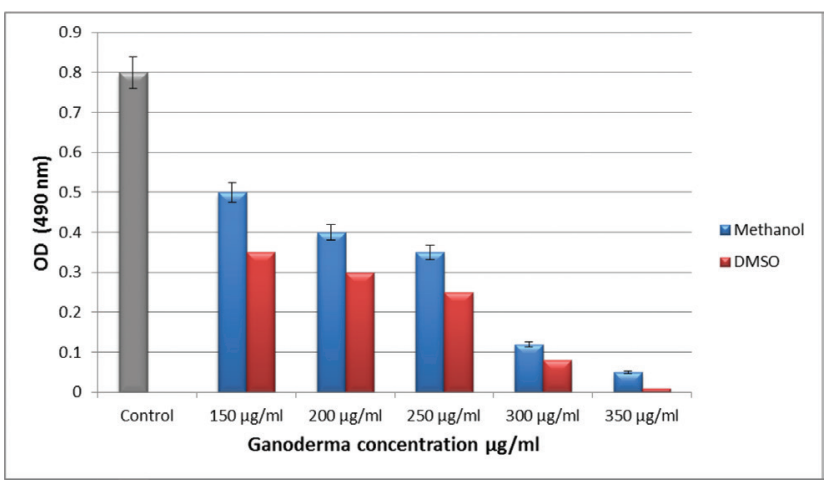

Bar Diagram: 1 - MIC (XTT Bioflim Reduction Assay).

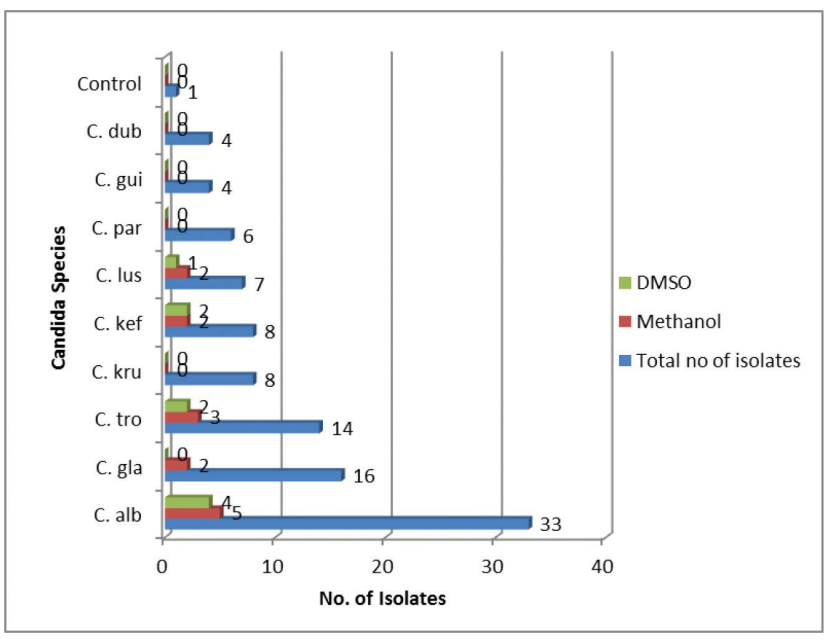

Bar Diagram: 2 MFC No. of Organisms grown.

Candida Species had the highest and significant value of MIC $(150 \mu \mathrm{g} / \mathrm{ml})$, while methanolic extracts of Candida Species had the highest MIC $(250 \mu \mathrm{g} / \mathrm{ml})$. The MIC of C. tropicalis, C. kefyr, C. guilliermondii and C. dubliniensis were 150,200, $250 \mu \mathrm{g} / \mathrm{ml}$, respectively, and these species whose two extracts showed fungistatic activity in all the concentrations, details are mentioned in the Table 3 and Bar diagram-1. The MFC of C. krusei, C. parapsilosis, C. guilliermondii, and C. dubliniensis

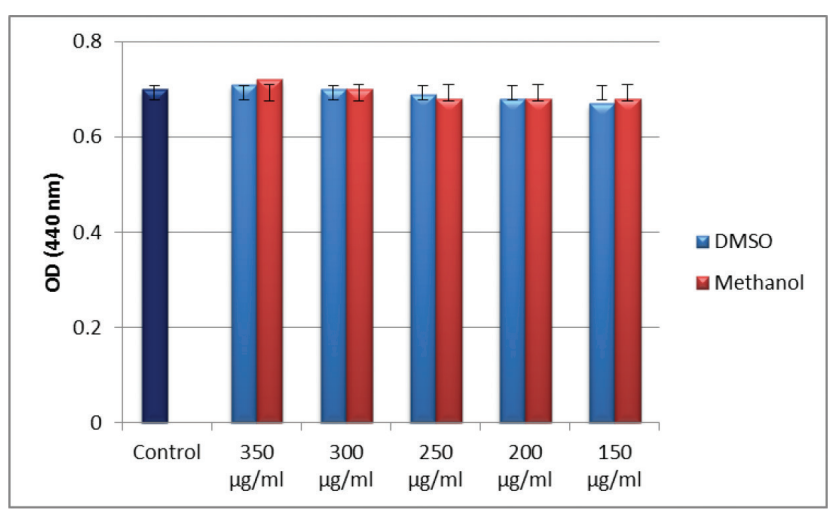

Bar Diagram: 3 Proteinase enzyme secretion assay.

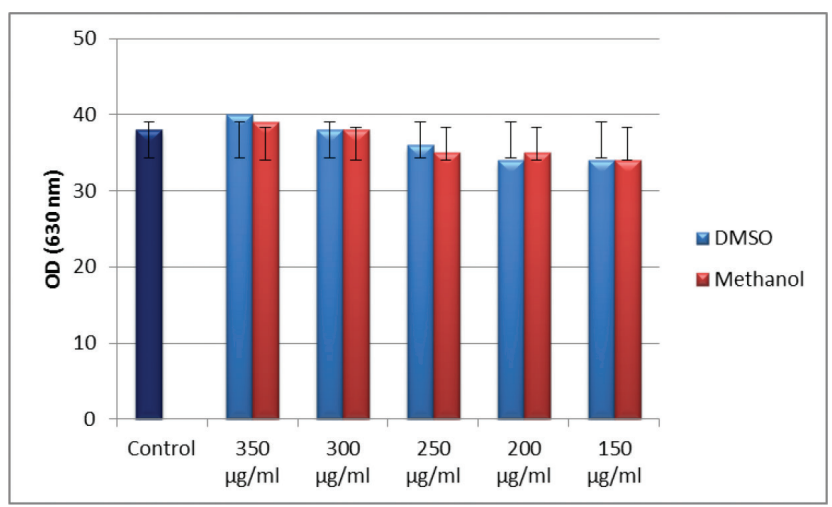

Bar Diagram: 4 Phospholipase enzyme secretion assay.

and these species whose two extracts showed fungicidal activity in all the concentrations, datas are explained in the Table 4 and bar diagram-2. XTT assay for the bioflims production and to screen the antifungal activity of various crude extracts. The OD value of the MIC shows significant value in the lowest concentration of the various candida species. Both the extracts of the Ganoderma crude extract given various significant values. But the ratio of the both fungistatic and fungicidal 


\begin{tabular}{|c|c|c|c|c|c|c|c|c|}
\hline \multicolumn{9}{|c|}{ Table 2: Candida spp. Isolated from various clinical specimens. } \\
\hline & Candida spp. & Urine & $\begin{array}{c}\text { Oropharyngeal } \\
\text { swab }\end{array}$ & $\begin{array}{c}\text { Vaginal } \\
\text { swab }\end{array}$ & Blood & CSF & Miscellaneous & $\begin{array}{c}\text { Total } \\
\text { and \% }\end{array}$ \\
\hline & C. albicans & 12 & 04 & 05 & 04 & 02 & 06 & 33 \\
\hline & C. glabrata & 05 & 03 & 02 & 03 & 02 & 01 & 16 \\
\hline & C. tropicalis & 04 & 02 & 05 & 02 & 00 & 01 & 14 \\
\hline & C. krusei & 03 & 03 & 00 & 00 & 00 & 02 & 08 \\
\hline & C. kefyr & 02 & 02 & 04 & 00 & 00 & 00 & 08 \\
\hline & C. lusitaniae & 01 & 02 & 00 & 02 & 00 & 02 & 07 \\
\hline & C. parapsilosis & 02 & 03 & 00 & 00 & 00 & 01 & 06 \\
\hline & C. guilliermondii & 01 & 01 & 02 & 00 & 00 & 00 & 04 \\
\hline & C. dubliniensis & 00 & 02 & 02 & 00 & 00 & 00 & 04 \\
\hline
\end{tabular}

\begin{tabular}{|c|c|c|}
\hline \multirow[t]{2}{*}{ Candida Species } & \multicolumn{2}{|c|}{ MIC no of isolates } \\
\hline & $\begin{array}{l}\text { DMSO Extract in } \mu \mathrm{g} / \mathrm{ml} \\
350300250200150\end{array}$ & $\begin{array}{l}\text { Methanolic Extract in } \mu \mathrm{g} / \mathrm{m} \\
350300250200150\end{array}$ \\
\hline C. albicans & ++++02 & +++0202 \\
\hline C. glabrata & +++++ & ++++01 \\
\hline C. tropicalis & +++++ & +++++ \\
\hline C. krusei & ++++02 & ++01010 \\
\hline C. kefyr & +++++ & +++++ \\
\hline C. Iusitaniae & ++++02 & ++++03 \\
\hline C. parapsilosis & +++++ & ++++01 \\
\hline C. guilliermondii & +++++ & +++++ \\
\hline C. dubliniensis & +++++ & +++++ \\
\hline
\end{tabular}

+; No OD Value

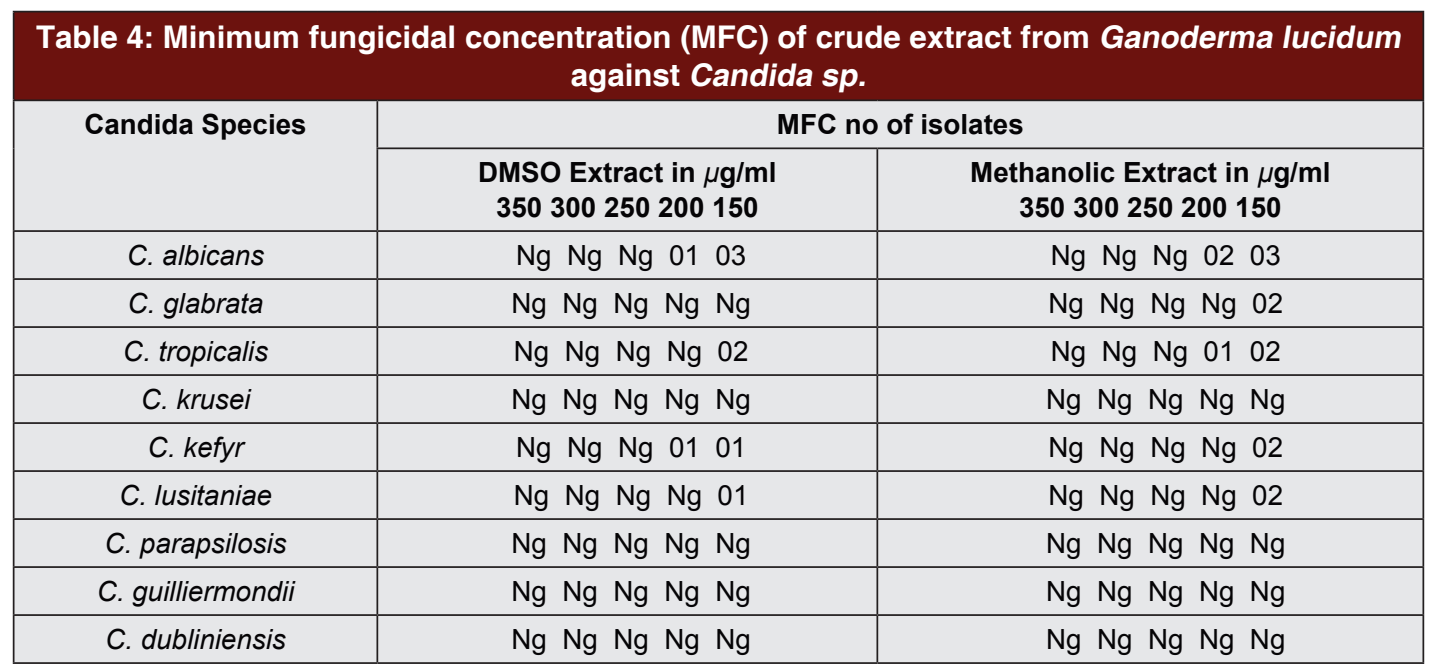

Ng; No Growth

activity of the DMSO crude extract shows high significant value $(\mathrm{P}<0.05)$ while compare to the methanolic extract of the Ganoderma lucidum. The MIC minimal value of $C$ albicans show 02 isolates in the $150 \mu \mathrm{g} / \mathrm{ml}$ concentration at the DMSO extract but the 04 isolates were show in the methanol extract 02 isolate at $200 \mu \mathrm{g} / \mathrm{ml}$ and 02 at $150 \mu \mathrm{g} / \mathrm{ml}$. The values were differed in the MFC 03 isolates in the DMSO extract 01 at $200 \mu \mathrm{g} / \mathrm{ml}$ and 02 at $150 \mu \mathrm{g} / \mathrm{ml}$ but the methanol extract show 05 isolates 02 at $200 \mu \mathrm{g} / \mathrm{ml}$ and 03 at $150 \mu \mathrm{g} / \mathrm{ml}$. The 
C. glabrata of the MIC and MFC are given significant value of the all the concentrations, the methanolic extract show 01 isolate in MIC and 02 isolate in the MFC at the $150 \mu \mathrm{g} / \mathrm{ml}$ concentration. The C. tropicalis and C. kefyr shows the significant value in the MIC at all the concentrations, while in methanolic extract of both the extracts of $200-150 \mu \mathrm{g} / \mathrm{ml}$ concentrations gives about 10 isolates. C. krusei and C. parapsilosis in MIC of both extracts show 06 isolates of the concentration between $150-250 \mu \mathrm{g} / \mathrm{ml}$ while in the MFC it shows significant value of the all the concentrations. C. lusitaniae in MIC shows 05 isolates, 02 isolates in the DMSO and 03 isolates at Methanol at $150 \mu \mathrm{g} / \mathrm{ml}$ while in MFC shows 03 isolates 01 isolate in the DMSO and 02 isolates at Methanol at $150 \mu \mathrm{g} / \mathrm{ml}$. Isolates of C. guilliermondii and $C$. dubliniensis show significant ratio at fungistatic and fungicidal activity in both DMSO and methanolic extract of all the concentrations of both MIC and MFC assays. According to the results obtained, Proteinase and phospholipase enzyme assay has been performed to know the modifications among the enzymes produced by the biofilm Candida species. Supernatants of biofilms, which were treated with various concentrations of the DMSO and Methanolic Ganoderma extract, showed no significant difference in either the enzyme activity of proteinases and phospholipases, when compared to the Control group are described in the Bar diagram 3 and 4. Thus, there was no reduction in enzyme activities; such findings suggest no modulatory effects by the Ganoderma lucidum against the bioflim producers. Furthermore the extraction yields of DMSO and Methanol extracts are quite similar. However, greater efficiency in the extraction of solutes is not directly related to greater inhibition. In this regard, DMSO extracts proved to have more activity against Candida species than Methanolic extracts. Thus, it can be concluded that the DMSO extracts $(200 \mu \mathrm{g} / \mathrm{ml}-150$ $\mu \mathrm{g} / \mathrm{ml}$ ) of Ganoderma lucidum in MIC and MFC showed higher significant value than those of the Methanol extract $(250 \mu \mathrm{g} / \mathrm{ml}-200 \mu \mathrm{g} / \mathrm{ml})$. Also we conclude that the DMSO extract exhibit high significant of fungistatic and fungicidal properties that support their traditional use as antiseptics and treatment against the Bioflim producing candida species.

\section{CONCLUSION}

The results obtained from this work showed that extracts of Ganoderma lucidum medicinal mushroom screened exhibit antifungal effects against biofilm producing Candida sp. In particular, while comparing to the Methanolic extract and DMSO extract, DMSO offer effective bioactive compounds for growth inhibition of the Candida and its Biofilm. Even at low concentrations, these species showed antifungal activity neither than the commercial fungicide according to the previous studies. So we can be conclude that DMSO extract of the Ganoderma lucidum shows high significant factor against the various disease causing Candida species and its Biofilm.

\section{ACKNOWLEDGEMENT}

I thank Dr. R. Chidambaram, who aided to screen the Ganoderma lucidum and I also thank Dr. R. Srikumar for reviewing the manuscript for the publication.

\section{CONFLICT OF INTEREST}

None of the authors has a conflict of interest to disclose.

\section{ABBREVIATIONS USED}

NAC: Non albican candida, MIC: Minimum Inhibitory Concentration, MFC: Minimum Fungicidal Concentration, DMSO: Dimethyl Sulfoxide, YNB: Yeast Nitrogen Base Medium, PBS: Phosphate Buffer Saline, XTT: (2, 3-bis (2-methoxy-4-nitro-5-sulfophenyl)-2H-tetrazolium-5-carboxanilide, RPMI: Roswell Park Memorial Institute Medium.

\section{REFERENCES}

1. Butler MS. The role of natural product chemistry in drug discovery. J Nat Prod. 2004;67(12):2141-53.

2. Lam KS. New aspects of natural products in drug discovery. Trend Microbiol. 2007;15(6):6279-89.

3. Alves MJ, Ferreira ICFR, Dias J, Teixeira V, Martins A, Pintado M. A review on antimicrobial activity of mushroom (Basidiomycetes) extracts and isolated compounds. Planta Med. 2012;78(16):1707-18.

4. Wasser SP, Weis AL. Medicinal properties of substances occurring in higher basidiomycetes mushrooms: current perspectives (Review). Int J Med Mush. 1999b;1:31-62.

5. Yoon SY, Eo SK, Kim YS, Lee CK, Han SS. Antimicrobial activity of Ganoderma extract alone Antimicrobial effects of Ganoderma 140. Afr J Biomed Res. 1994;13(2): Jonathan and Awotona and in combination with some antibiotics. Archives of Pharmacol Reseach. 2010;17(6):438-42

6. Klaus A, Miomir N. Influence of the extracts isolated from Ganoderma lucidum mushroom on some microorganisms. Proceedings of National Science, Matica Srpska Novi Sad. 2007;113:219-26.

7. Sheena N, Ajith TA, Mathew AT, Janardhanan KK. Antibacterial activity of three macrofungi, Ganoderma lucidum, Navesporus floccosa and Phellinus rimosus occurring in South India. Pharmac Biol. 2003;41(8):564-7.

8. Quereshi S, Pandey AK, Sandhu SS. Evaluation of antibacterial activity of different Ganoderma lucidum extracts. J Sci Res. 2010;3:9-13.

9. Gao Y, Tang W, Gao H, Chan E, Lan J, Li X, et al. Antimicrobial bactivity of the medicinal mushroom Ganoderma. Food Rev Int. 2005;21(2):211-22.

10. Ramage G, Mart'inez JP, L'opez-Ribot JL. "Candida biofilms on implanted biomaterials: a clinically significant problem,". FEMS Yeast Research. 2006;6(7):979-86.

11. Shin JH, Kee SJ, Shin MG, et al. "Biofilm production by isolates of Candida species recovered from nonneutropenic patients: comparison of bloodstream 
isolates with isolates from other sources,". Journal of Clinical Microbiology. 2002;40(4):1244-8.

12. Tumbarello M, Posteraro B, Trecarichi EM, et al. "Biofilm production by Candida species and inadequate antifungal therapy as predictors of mortality for patients with candidemia,". Journal of Clinical Microbiology. 2007;45(6):1843-50.

13. Wey SB, Mori M, Pfaller MA, Woolson RF, Wenzel RP. Hospital-acquired candidemia. The attributable mortality and excess length of stay. Arch Intern Med. 1988;148(12):2642-5.

14. Finkel JS, Mitchell AP. Genetic control of Candida albicans biofilm development. Nat Rev Microbiol. 2011;9(2):109-18.

15. Baillie GS, Douglas LJ. Candida biofilms and their susceptibility to antifungal agents. Methods Enzymol. 1999;310:644-56.

16. Chandra J, Mukherjee PK, Leidich SD, Faddoul FF, Hoyer LL, Douglas LJ, et al. Antifungal resistance of candidal biofilms formed on denture acrylic in vitro. J Dent Res. 2001;80:903-8.

17. Budtz-Jorgensen E. Etiology, pathogenesis, therapy, and prophylaxis of oral yeast infections. Acta Odontol Scand. 1990;48(1):61-9.

18. Budtz-Jorgensen E. Histopathology, immunology, and serology of oral yeast infections. Diagnosis of oral candidosis. Acta Odontol Scand. 1990;48(1):37-43.

19. Donlan RM. "Biofilms: microbial life on surfaces," Emerging Infectious Diseases. 2002;8(9):881-90.

20. Samaranayake LP, MacFarlane TW. 1990. Oral candidosis. London: WrightButterworth.

21. Naglik JR, Rodgers CA, Shirlaw PJ, Dobbie JL, Fernandes-Naglik LL, Greenspan D, et al. Differential expression of Candida albicans secreted aspartyl proteinase and phospholipase B genes in humans correlates with active oral and vaginal infections. J Infect Dis. 2003;188(3):469-79.

22. Rosa LH, Machado KMG, Jacob CC, Capelari M, Rosa CA, Zani CL. Screening of Brazilian Basidiomycetes for antimicrobial activity. Memórias do Instituto Oswaldo Cruz. 2003;98(7):967-74.

23. Phillips R. (1981). Mushrooms and other fungi of Great Britain and Europe. London, United Kingdom: Macmillan Publishers Ltd.

24. Hall IR, Stephenson SL, Buchanan PK, Yun W, Cole ALJ. (2003). Edible and Poisonous Mushrooms of the World. Timber Press Inc., Oregon, USA, 372p.

25. Oria de Rueda JA. (2007). Hongos y setas. Tesoro de nuestros montes. Palencia, Spain: E diciones Cálamo.

26. Steyaert RL. Species of Ganoderma and related genera mainly of the Bogor and Leiden herbaria. Persoonia. 1972;7:55-118.

27. Dandan L, Zheng H, Zhiang L, Bo Y, Wenjuan T, Liang Lia. Chemical composition and antimicrobial activity of essential oil isolated from the cultured mycelia of Ganoderma japonicum. Laboratory Industrial Microbiol. 2009;9(3):122-5.

28. Dulger B, Gonuz A. Antimicrobial activity of certain plants used in Turkish traditional medicine. Asian Journal of Plant Sciences. 2004;3(1):104-7.

29. Bauer AW, Kirby WM, Sherris JC, Turck M. Antibiotic susceptibility testing by a standardized single method. American Journal of Clinical Pathology. 1966;45:493.
30. NCCLS Standards, Performance standards for antimicrobial disk susceptibility tests: Approval standard M2- A7 $7^{\text {th }}$ edition. Pennsylvania: Clinical and Laboratory Standards Institute, (2000).

31. Goncalves LM, Del Bel Cury AA, Sartoratto A, Garcia RVL, Silva WJ. Effects of undecylenic acid released from denture liner on Candida biofilms. Journal of Dental Research. 2012;91(10):985-9. DOI 10.1177/0022034512458689.

32. Pande M, Dubey VK, Yadav SC, Jagannadham MV. A novel serine protease cryptolepain from Cryptolepis buchanani: purification and biochemical characterization. Journal of Agricultural and Food Chemistry. 2006;54(26):10141-50. DOI 10.1021/jf062206a.

33. Santana IL, Goncalves LM, De Vasconcellos AA, Da Silva WJ, Cury JA, Del Bel Cury AA. Dietary carbohydrates modulate Candida albicans biofilm development on the denture surface. PLoS ONE. 2013;8(5):e64645. DOI 10.1371/journal.pone.0064645.

34. Taniguchi L, De Fatima FB, Rosa RT, De Paula ECA, Gursky LC, ElifioEsposito SL, et al. Proposal of a low-cost protocol for colorimetric semiquantification of secretory phospholipase by Candida albicans grown in planktonic andbiofilm phases. Journal of Microbiological Methods. 2009;78(2):171-4. DOI 10.1016/j.mimet.2009.05.012.

35. Chandra J, Kuhn DM, Mukherjee PK, Hoyer LL, McCormick T, Ghannoum MA. "Biofilm formation by the fungal pathogen Candida albicans: development, architecture, and drug resistance,". Journal of Bacteriology. 2001;183(18):5385-94.

36. Ramage G, Vande WK, Wickes BL, L'opez-Ribot JL. "Standardized method for in vitro antifungal susceptibility testing of Candida albicans biofilms," Antimicrobial Agents and Chemotherapy. 2001;45(9):2475-9.

37. Pasetto S, Pardi V, Murata RM. Anti-HIV-1 activity of flavonoid myricetin on HIV-1 infection in a dual-chamber in vitro model. PLoS ONE. 2014;9(12):e115323. DOI 10.1371/journal.pone.0115323.

38. Hawser SP, Norris H, Jessup CJ, Ghannoum MA. Comparison of a 2,3-bis(2methoxy-4-nitro-5-sulfophenyl)-5-[(phenylamino)carbonyl]-2H-t etrazolium hydroxide (XTT) colorimetric method with the standardized National Committee for Clinical Laboratory Standards method of testing clinical yeast isolates for susceptibility to antifungal agents. J Clin Microbiol. 1998;36:1450-2.

39. Honraet K, Goetghebeur E, Nelis HJ. Comparison of three assays for the quantification of Candida biomass in suspension and CDC reactor grown biofilms. J Microbiol Methods. 2005;63:287-95.

40. Espinel-Ingroff A, Fothergill A, Peter J, Rinaldi MG, Walsh TJ. Testing conditions for determination of minimum fungicidal concentrations of new and established antifungal agents for Aspergillus spp.: NCCLS Collaborative Study. Journal of Clinical Microbiology. 2002;40:3204-8.

41. National Committee for Clinical Laboratory Standards (NCCLS). 2002. Reference method for broth dilution antifungal susceptibility testing of yeast fungi. Approved standard M38-A2. Wayne: National Committee for Clinical Laboratory Standards.

42. Nithya M, Ambikapathy V, Panneerselvam V. "Studies on ntimicrobial Potential of Different Strains of Ganoderma lucidum (Curt.: Fr.) P. Karst." Int J Pharm Sci Rev Res. 2013;21(2):317-20.

\section{SUMMARY}

- Ganderma lucidum is an edible mushroom has more Medicinal values.

- Dimethyl sulfoxide (DMSO) and Methanol Extracts of Ganderma lucidum were treated against the Candida albicans and Non albicans Organisms which causes both superficial and systemic infections.

- Screened for Proteinase and phospholipase enzyme secretion assay, Minimum Inhibitory Concentration (MIC) - XTT Assay and Minimal Fungicidal Concentration (MFC)

- DMSO extract of the Ganoderma lucidum shows high inhibition factor against the various disease causing Candida species and its biofilm. 


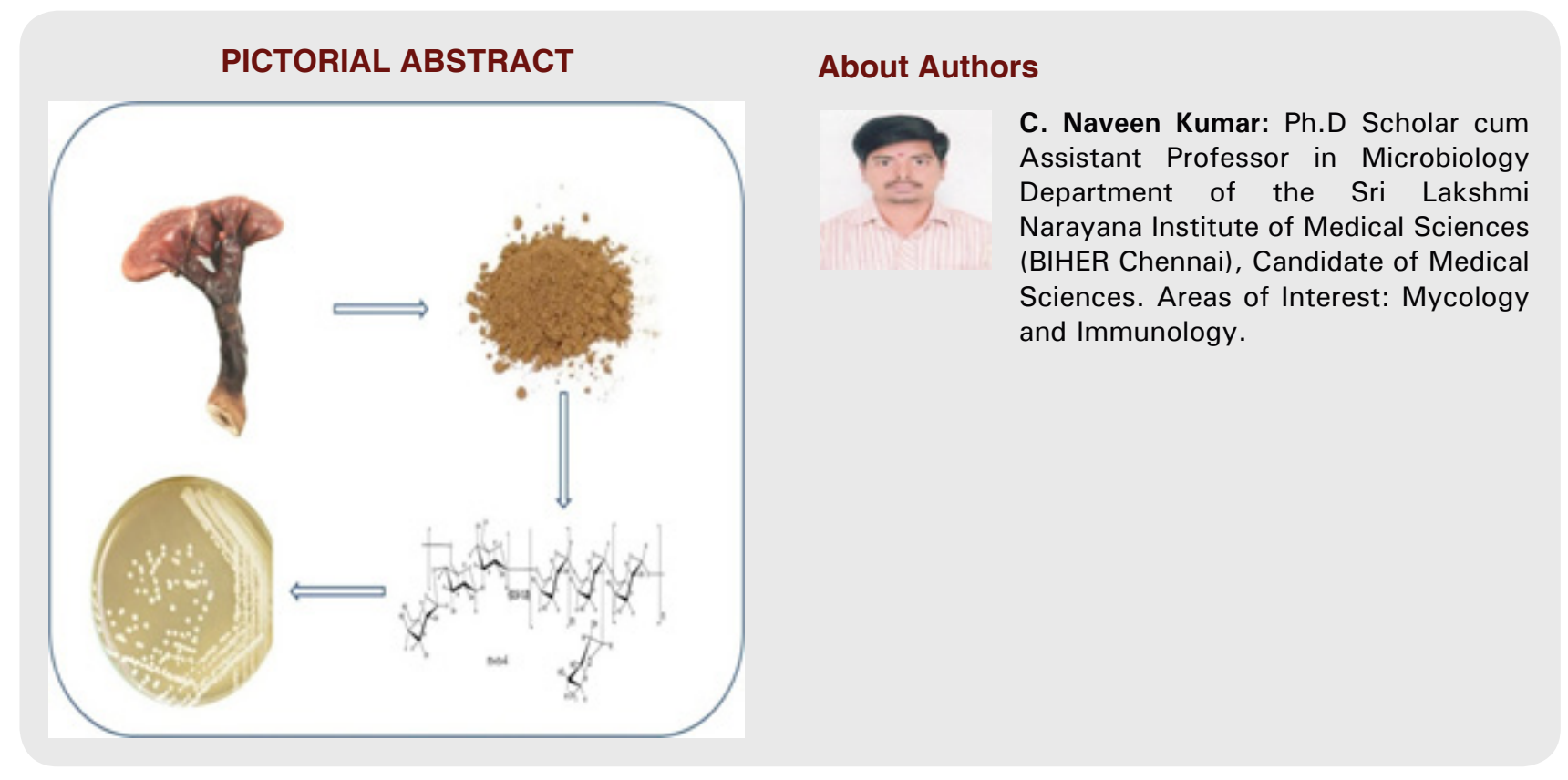

Cite this article: kumar NC, Jayalakshmi G, Chidambaram, Srikumar R. In-vitro Evaluation of Antifungal Activity of Ganoderma lucidum Against the Biofilm Producing Candida species. Indian J of Pharmaceutical Education and Research. 2017;51(4S):S623-S30. 